\title{
The impact of foreign direct investment on capital formation in Nigeria: A co-integration approach
}

\author{
Ugwuegbe, Sebastine Ugochukwu ${ }^{1}$, Modebe, Nwanneka Judith ${ }^{1}$, Onyeanu Edith ${ }^{2}$ \\ ${ }^{1}$ Department of Banking and Finance, University of Nigeria, Enugu, Nigeria \\ ${ }^{2}$ Department of Accountancy, University of Nigeria, Enugu, Nigeria
}

Email address:

ugossbros@yahoo.com ( Ugwuegbe. S.U)

\section{To site this article:}

Ugwuegbe, Sebastine Ugochukwu, Modebe Nwanneka Judith, Onyeanu Edith. The Impact of Foreign Direct Investment on Capital Formation in Nigeria: A Co-Integration Approach. International Journal of Economics, Finance and Management Sciences. Vol. 2, No. 2, 2014, pp. 188-196. doi: 10.11648/j.ijefm.20140202.21

\begin{abstract}
In this work, we investigated the impact of FDI on capital accumulation in Nigeria for the period of 1986-2012. The data was generated from CBN statistical bulletin, OLS method of estimation was adopted for the analysis of the data generated. ADF test was applied to determine the stationarity of the variables and all the variables were integrated at order one I(1). The Johanson co-integration test shows the existence of at most 2 co-integrating equation in the model. The ECM indicates that $73.24 \%$ of the disequilibrium in the model will be corrected on annual bases. The OLS estimation indicates that FDI, TCR, and INTR positively but insignificantly effect capital formation in the short-run whit GEXP exerting negative effect on GFCF. The result also indicate that in the long-run all the variables included in the model has a positive impact on GFCF with only FDI and TCR exerting a significant impact on capital accumulation in Nigeria for the period under review. There is bidirectional causality between FDI and GFCF. Effort should be made by government to attract more FDI into the country as it has the potential to improve the capital formation in the economy which in the other hand leads to growth in the economy at large. It is also important that government should improve the infrastructural facility in the country as this has a great potential for attracting more FDI into the country. The issue of insecurity should also be addressed without delay if we are to move the economy to the desired direction.
\end{abstract}

Keywords: Foreign Direct Investment, Gross Fixed Capital Formation, Total Bank Credit to Private Sector, Interest Rate, Government Expenditure, Co-integration

\section{Introduction}

According to Ghirmay and Cadet (1998) Foreign direct investment (FDI) refers to the ownership of assets in a foreign country. It occurs in two ways. One involves the acquisition of domestic firms by foreign investors, including the purchase of stocks in domestic corporations in which the foreign investor has significant equity. The other method of foreign direct investment is the construction of new production facilities in the foreign country - either brand-new subsidiaries or expansion of existing subsidiaries. Foreign direct investment involves not only a transfer of resources but also the acquisition of control. In most cases, the subsidiaries not only have a financial obligation to the parent company, but it is part of the same organizational structure. World Bank (1996), looked at FDI as an investment made to acquire a lasting management interest (normally 10\% of voting stock) in a firm or an enterprise operating in a country other than that of the investor defined according to residency. However, Foreign Direct Investment (FDI) is often seen as an important catalyst for economic growth in the developing countries because it affects the economic growth by stimulating domestic investment, increase in capital formation and by facilitating the technology transfer in the host countries. (Falki 2009).

According to Ugwuegbe at, el (2012) the underdeveloped nature of the Nigerian economy that essentially hindered the pace of her economic development has necessitated the demand for Foreign Direct Investment into the country. Nigeria as one of the developing countries of the world, has adopted a number of measures aimed at accelerating growth and development in the domestic economy, one of which is to attract foreign direct investment (FDI). This is in line with the understanding that FDI contributes positively to the growth of domestic economy. 
Khan (2007) asserts that Foreign Direct Investment (FDI) has emerged as the most important source of external resource flows to developing countries over the years and has become a significant part of capital formation in these countries, though their share in the global distribution of FDI continued to remain small or even declining. The role of Foreign Direct Investment (FDI) has been widely recognized as a growth-enhancing factor in the developing countries.

Multinational corporations are the major players in foreign direct investment. They often establish new businesses in foreign countries or provide the foreign subsidiaries with capital, in the expectation of creating a profitable integration of their operations. Many factors determine multinational corporations' decision about where to locate foreign subsidiaries or undertake significant foreign direct investment.

Ghirmay and Cadet (1998) identified these key factors responsible for the location of foreign subsidiaries to include low unit labor costs, adequate economic infrastructure, large domestic markets, government regulations, and political instability in the host country. Most big corporations now have foreign subsidiaries supplying components to the parent company or producing the same good or service. And this has lead to increase in the volume of capital accumulation in the host country.

On the other hand Bakare (2011) refers to Capital formation as the proportion of present income saved and invested in order to augment future output and income. It usually results from acquisition of new factory along with machinery, equipment and all productive capital goods. Capital formation is equivalent to an increase in physical capital stock of a nation with investment in social and economic infrastructure. Gross fixed capital formation can be classified into gross private domestic investment and gross public domestic investment. The gross public investment includes investment by government and public enterprises. Gross domestic investment is equivalent to gross fixed capital formation plus net changes in the level of inventories.

Economic theories have shown that capital formation plays a crucial role in the models of economic growth (Beddies 1999; Gbura and THadjimichael 1996, Gbura, 1997). This view called capital fundamentalism by Youopoulos and Nugent (1976) has been reflected in the macroeconomic performances of many countries. It is clear that even mildly robust growth rates can be sustained over long periods only when countries are able to maintain capital formation at a sizeable proportion of GDP.

Nigeria is one of the few countries that have benefited from the FPI inflow to Africa. Nigeria's share of FPI inflow to Africa averaged around $10 \%$, from $24.19 \%$ in 1990 to a low level of $5.88 \%$ in 2001 up to $11.65 \%$ in 2002 (CBN, 2004). UNCTAD (2004) showed Nigeria as the continent's second top FPI recipient after Angola in 2001 and 2002. The nominal FPI inflow ranged from N128.6 million in 1970 to N434.1 million in 1985 and N115.952 billion in
2000. This was an increase in real terms from the decline of the 1980s. FPI forms a small percentage of the nation's gross domestic product (GDP), however, making up $2.47 \%$ in $1970,-0.81 \%$ in $1980,6.24 \%$ in 1989 and $3.93 \%$ in 2002. (CBN, 2006).

Many researchers have looked at the impact of FDI on the growth of Nigerian economy (Umah (2007), Shiro (2009), Bello (2003), Adelegan (2000), Akinlo (2004), Aremu (1997), Otepola, (2002)) with mixed findings arising from different studies on different time periods as well as different methodology. Not many of these studies have actually taking a closer look at the long run relationship that exists between FDI and capital formation in Nigeria. The only attempt to consider this is the study of Orji and Mba (2011) that employed Cobb-Douglas production function in determining the long run relationship between FPI, Capital Formation and Economic Growth in Nigeria. Although they fund that there is a long run relationship between FPI, capital formation and economic growth, no attempt was made to determine the direction of causality between them.

On the same vain Ghirmay and Cadet (1998) looked at the impact of FDI on private capital formation in SubSahara African countries. Meanwhile the objective of this study is to find out to what extent has this FDI inflows to Nigeria contributed to the growth of capital formation in Nigeria as well as the long run relationship between these variables. The direction of causality between these variables will also be determined. This is the gap that this work seeks to fill.

The rest of the paper is structured as follow: after this brief introduction, section II will reviews some related literature, in section III, we looked at the methodology, while section IV, presented the data analysis, and in section $\mathrm{V}$, we presented summary of the findings, the implications of the findings as well as the policy recommendations.

\section{Review of Related Literatures}

A number of studies have analyzed the relationship between FDI inflows and economic growth, but the issue is far from settled in view of the mixed findings reached. Ugwuegbe (2012) noted that the center-piece of the noeliberal School otherwise known as the Pro-Foreign Investment School is that FDI can provide crucial help in modernizing the industrial order for the developing countries. They also believed that Trans-national Corporations (TNCs), through their FDI, could provide much of the 'motor' needed for economic growth in developing countries (Penrose, 1961 and Chenery and Stout, 1966).

As opposed to the claim of the dependency theorists that FDI leads to transfer of economic control and wealth to foreign powers ultimately leading to economic marginalization of the FDI host countries, neo-liberals argue that FDI provides vast benefits to recipient firm and host economies of TNCs affiliates (Matzner, 1996). Firstly, 
they believe that FDI brings crucial western knowledge and value in the form of superior Western management qualities, business ethics, entrepreneurial attitudes, better labour/capital ratio, and production techniques. Secondly, FDI makes possible industrial grading by tying firms of developing countries hosting TNCs affiliates into global research and development (R\&D) networks, and thus resulting in technology transfer as well as providing a greater deal of investment fund (Fisher and Gelb 1991). Thirdly, FDI leads to the growth of enterprises by providing access to Western markets. This growth in turn provides a source of new jobs and stimulates demand for input from domestic suppliers. And so, FDI introduces new market entrant beyond the domestic economies hosting TNCs affiliates (Apter, 1965).

However, Bende-Nabende and Ford (1998) submit that the wide externalities in respect of technology transfer, the development of human capital and the opening up of the economy to international forces, among other factors that come along with FDI, have served to change the pace of economic growth.

According to Buckley, et al. (2002) However, the extent to which FDI contributes to growth depends on the economic and social conditions or, in short, the quality of environment of the recipient country. This quality of environment he noted relates to the rate of savings in the host country, the degree of openness and the level of technological development. Host countries with high rate of savings, open trade regime and high technological product would benefit from increased FDI to their economies.

De Gregorio (2003) while contributing to the debate on the importance of FDI, notes that FDI may allow a country to bring in technologies and knowledge that are not readily available to domestic investors and, in this way, increase productivity growth throughout the economy. FDI may also bring in expertise that the country does not possess, and foreign investors may have access to global markets; in fact, he found that increasing aggregate investment by 1 percentage point of GDP increased economic growth of Latin American countries by $0.1 \%$ to $0.2 \%$ a year, but increasing FDI by the same amount increased growth by approximately $0.6 \%$ a year during the period 1950-1985, thus indicating that FDI is three times more efficient than domestic investment.

De Gregorio, (2003) did a panel data analysis of 12 Latin American countries in the period 1950-1985 and his results suggest a positive and significant impact of FDI on economic growth. In addition, he noted that the productivity of FDI is higher than the productivity of domestic investment for the period under review. Findings of $\mathrm{Xu},(2000)$ for US FDI in 40 countries for the period 1966-1994 also support the findings of De Mello (1990) that technology transfer from FDI contributes to productivity growth in developed countries but not in developing countries, which he attributes to lack of adequate human capital.
In contrast to this submission by the pro-foreign investment school, the dependency theory advocates see FDI as the advanced guard for a new diplomacy of economic imperialism (Bailey, 1995; Inziet, 1994; Aslund, 1995; Ake, 1996; Landsburg, 1979; Hejidra, 2002). This school is of the opinion that FDI adversely affect the development of the host country by disarticulated development, exploitation of the domestic economy by the TNCs, creating room for uneven development between the industrially developed nation and that of developing and developed nations alike. They also argued that it perverts social and political structure of the host nations as well destroy their cultural pattern.

Gilpin (1987) asserts that dependency theorists recommended that what is needed to end the exploitation mentioned above is the destruction of the linkage between international capitalism and the domestic economy. This, he noted, can be achieved through the political triumph of a revolutionary national leadership that will overthrow the clientele elite and replace it with one desirous of independent economic development programs.

Durham (2004), for example, failed to establish a positive relationship between FDI and growth, but instead suggests that the effects of FDI are contingent on the "absorptive capability" of host countries. Firebaugh (1992) lists several additional reasons why FDI inflows may be less profitable than domestic investment and may even be detrimental. The country may gain less from FDI inflows than domestic investment because multinationals are less likely to contribute to government revenue; FDI is less likely to encourage local entrepreneurship; multinationals are less likely to reinvest profits; they are less likely to develop linkages with domestic firms; and are more likely to use inappropriately capital-intensive techniques. FDI may be detrimental if it crowds out domestic businesses and stimulates inappropriate consumption pattern.

There has not been a consensus in the findings of different scholars as to how FDI contribute to the growth of domestic economy. This however can be attributed to the inability of these researchers to take a look at the impact of FDI on major macroeconomic variables. Little or no study has actually considered the impact of FDI on capital formation which is crucial for economic growth and development of any domestic economy. Economic theories have shown that capital formation plays a crucial role in the models of economic growth (Beddies 1999; Gbura and THadjimichael 1996, Gbura, 1997). This view called capital fundamentalism by Youopoulos and Nugent (1976) has been reflected in the macroeconomic performances of many countries.

According to Bakare (2011) in 1986, the government of Nigeria considered the need for improvement in capital information and pursued an economic reform that shifted emphasis on private sector. The public sector reforms were expected to ensure that interest rates were positive in real terms and to encourage savings, thereby ensuring that investment funds would be readily available to the real 
sector. Besides this, the reforms were expected to lead to efficiency and productivity of labor; efficient utilization of economic resources, increase aggregate supply, reduces unemployment and generate low inflation rate. For example, during 1980s, gross fixed capital information average 21.3 percent of GDP in Nigeria. This proportion increased to 23.3 percent of GDP in 1991 and declined to 14.2 percent of GDP in 1996. It picked and increased to 17.4 percentage in 1997 and average 21.7 during 1997 to 2000. The gross capital formation rose from 22.3 percent of GDP in 2000 to 26.2 percent in 2002 and declined drastically to 21.3 percent in 2005 .

Apart from a study done by Ghirmay and Cadet (1998), in which he looked at the impact of FDI on private capital formation in Sub-Sahara African with Nigeria inclusive, no attempt have been made by any author to examine the impact of FDI on capital formation with a particular reference to Nigeria. This however is the gap that this work seeks to fill.

\section{Model Specification}

This study seeks to determine the impact of FDI on capital formation in Nigeria for a period 1986-2012. And to achieve this, a log form of OLS regression model will be adopted for this work. This is to enable us improve on the linierity of the model and also to avoid heteroskedasticity.

$$
\text { GFCF }=\mathrm{f}(\text { FDI, GEXP, INTR, and TCR })
$$

Explicitly the above equation can be stated thus:

$\mathrm{GFCF}=\beta_{0}+\beta_{1} \mathrm{FDI}+\beta_{2} \mathrm{GEXP}+\beta_{3} \mathrm{INTR}+\beta_{4} \mathrm{TCR}+\mathrm{Ut}$

The log form of the model is stated as follows.

$\log ($ GFCF $)=\beta_{0}+\beta_{1} \log ($ FDI $)+\beta_{2} \log ($ GEXP $)+\beta_{3} \log ($ INT

$$
\text { R) }+\beta_{4} \log (\mathrm{TCR})+\mathrm{Ut}
$$

Where

$$
\begin{aligned}
& \text { GFCF = Gross Fixed Capital Formation } \\
& \text { FDI = Foreign Direct Investment } \\
& \text { GEXP = Government Expenditure } \\
& \text { INTR = Interest Rate } \\
& \text { TCR = Total Credit to the Private sector }
\end{aligned}
$$

\subsection{Test of Best Regression}

To determine if the above model is the best model to explain this relationship, the following condition must be met:

$1 \mathrm{R}^{2}$ must be high at least above $60 \%$

2 There will be no serial autocorrelation in the model.

3 The residual must be normally distributed.

4 There will be no heteroskedasticity in the model, in other words the model must be homoskedastic.

When all this condition is met, the model will be regarded as the best regression model to explain the relationship between GFCF and FDI in Nigeria.

\subsection{Estimation Technique}

\subsubsection{Unit Root Test}

The first step involves testing the order of integration of the individual series under consideration. Researchers have developed several procedures for the test of order of integration. The most popular ones are Augmented DickeyFuller (ADF) test due to Dickey and Fuller (1979, 1981), and the Phillip-Perron (PP) due to Phillips (1987) and Phillips and Perron (1988). Augmented Dickey-Fuller test relies on rejecting a null hypothesis of unit root (the series are non-stationary) in favor of the alternative hypotheses of stationarity. The tests are conducted with and without a deterministic trend $(\mathrm{t})$ for each of the series. The general form of $\mathrm{ADF}$ test is estimated by the following regression

$$
\begin{array}{r}
\Delta \mathrm{y}_{\mathrm{t}}=\alpha^{0}+\alpha^{1} y^{t-1}+\sum_{i=1}^{n} \alpha \Delta y_{i}+\varepsilon^{t} \\
\Delta \mathrm{y}_{\mathrm{t}}=\alpha_{0}+\alpha_{1} y_{t-1}+\sum_{i=1}^{n} \alpha_{1} \Delta y_{i}+\delta_{t}+\varepsilon_{t}
\end{array}
$$

Where: $\mathrm{Y}$ is a time series, $\mathrm{t}$ is a linear time trend, $\Delta$ is the first difference operator, $\alpha_{0}$ is a constant, $n$ is the optimum number of lags in the dependent variable and $\varepsilon$ is the random error term; the difference between equation (4) and (5) is that the first equation includes just drift. However, the second equation includes both drift and linear time trend.

\subsubsection{Co-Integration Test}

The second step is the testing of the presence or otherwise of co integration between the series of the same order of integration through forming a co integration equation. The basic idea behind co integration is that if, in the long-run, two or more series move closely together, even though the series themselves are trended, the difference between them is constant. It is possible to regard these series as defining a long-run equilibrium relationship, as the difference between them is stationary (Hall and Henry, 1989). A lack of co integration suggests that such variables have no long-run relationship: in principal they can wander arbitrarily far away from each other (Dickey et. al., 1991). We employ the maximum-likelihood test procedure established by Johansen and Juselius (1990) and Johansen (1991). Specifically, if $Y t$ is a vector of $n$ stochastic variables, then there exists a p-lag vector auto regression with Gaussian errors of the following form: Johansen's methodology takes its starting point in the Vector Autoregression (VAR) of order $\mathrm{P}$ given by

$$
y_{t}=\mu+\Delta_{1} y_{t-1}+---+\Delta \rho y_{t-1}+\varepsilon_{t}
$$

Where Yt is an $\mathrm{nx} 1$ vector of variables that are integrated of order commonly denoted (1) and $\varepsilon t$ is an $n x 1$ vector of innovations.

This VAR can be rewritten as

$$
\Delta \mathrm{y}_{\mathrm{t}}=\mu+\eta_{y t-1}+\sum_{i-1}^{p-1} \tau_{i} \Delta y_{t-1}+\varepsilon_{t}
$$

Where 


$$
\Pi=\sum_{i-1}^{p} A_{i-1} \text { and } \tau_{i}=-\sum_{j=i+1}^{p} A j
$$

To determine the number of co-integration vectors, Johansen (1988, 1989) and Johansen and Juselius (1990) suggested two statistic test, the first one is the trace test $(\lambda$ trace). It tests the null hypothesis that the number of distinct co integrating vector is less than or equal to $\mathrm{q}$ against a general unrestricted alternatives $q=r$. the test calculated as follows:

$$
\operatorname{\lambda trace}(r)=-T \sum_{i=r+1} \operatorname{In}\left(1-\lambda_{\mathrm{i}}\right)
$$

Where $\mathrm{T}$ is the number of usable observations, and the $\lambda 1, \mathrm{~s}$ are the estimated eigenvalue from the matrix.

\subsubsection{Error Correction Mechanism}

After testing for the Co integration relationship and cointegration is proven to exist between the variables, then the third step will require a construction of an ECM to model the dynamic relationship. The reason behind ECM is to indicate the speed of adjustment from the short-run equilibrium to the long-run equilibrium state. However, the greater the co-efficient of the parameter, the higher the speed of adjustment of the model from the short-run to long-run equilibrium.

Where:

$$
\begin{gathered}
G F C F_{t}=\alpha_{0}+\sum_{i=1}^{n} \alpha_{1 t} G F C F_{t-1}+\sum_{i=1}^{p} \alpha_{2 t} F D I_{t-1}+\sum_{i=1}^{m} \alpha_{3 t} G E X P_{t-1} \\
+\sum_{i=1}^{j} \alpha_{4 t} I N T R_{t-1}+\sum_{i=1}^{k} \alpha_{5 t} T C R_{t-1}+\delta_{1} E C M_{t-1}+\varepsilon_{t}
\end{gathered}
$$

$\mathrm{GFCF}_{\mathrm{t}}=$ Gross Fixed Capital Formation at time $\mathrm{t}$

The term $\mathrm{ECT}_{\mathrm{t}-1}$ is the error correction term derived from the long-run co integrating relationship in the equation.

We note that the estimate $\delta 1$ can be interpreted as the speed of adjustment from short-run to long-run equilibrium. According to Johansen and Juselius (1987), the existence of cointegration implies the existence of the causality relation between the variables (GFCF and FDI, GEXP, INTR, TCR).

\subsubsection{Granger Causality Test}

The granger causality test is conducted with a view to determine the direction of causality between the variables under study. The existence of co-integration among the variables implies the existence of causal relationship between the variables (GFCF, FDI, GEXP, INTR, and TCR), but this does not tell us the direction of this causality hence the need for granger causality test to be conducted to enable us determine the direction of causality that exist among the variables. The following are the model for granger causality test.

$$
G F C F_{t}=\alpha_{0}+\sum_{i=1}^{n} \alpha_{1 t} G F C F_{t-1}+\sum_{i=1}^{p} \alpha_{2 t} F D I_{t-1}+\sum_{i=1}^{m} \alpha_{3 t} G E X P_{t-1}
$$

$$
\begin{gathered}
+\sum_{i=1}^{j} \alpha_{4 t} I N T R_{t-1}+\sum_{i=1}^{k} \alpha_{5 t} T C R_{t-1}+\varepsilon_{1 t} \\
F D I_{t}=\beta_{0}+\sum_{i=1}^{n} \beta_{1 t} F D I_{t-1}+\sum_{i=1}^{p} \beta_{2 t} G F C F_{t-1}+\sum_{i=1}^{m} \beta_{3 t} G E X P_{t-1} \\
+\sum_{i=1}^{j} \beta_{4 t} I N T R_{t-1}+\sum_{i=1}^{k} \beta_{5 t} T C R_{t-1}+\varepsilon_{2 t} \\
G E X P_{t}=\delta_{0}+\sum_{i=1}^{n} \delta_{1 t} G E X P_{t-1}+\sum_{i=1}^{p} \delta_{2 t} F D I_{t-1}+\sum_{i=1}^{m} \delta_{3 t} G F C F_{t-1} \\
+\sum_{i=1}^{j} \delta_{4 t} I N T R_{t-1}+\sum_{i=1}^{k} \delta_{5 t} T C R_{t-1}+\varepsilon_{3 t} \\
I N T R_{t}=\sigma_{0}+\sum_{i=1}^{n} \sigma_{1 t} I N T R_{t-1}+\sum_{i=1}^{p} \sigma_{2 t} F D I_{t-1}+\sum_{i=1}^{m} \sigma_{3 t} G E X P_{t-1} \\
+\sum_{i=1}^{j} \sigma \alpha_{4 t} G F C F_{t-1}+\sum_{i=1}^{k} \sigma_{5 t} T C R_{t-1}+\varepsilon_{4 t} \\
T C R_{t}=\pi_{0}+\sum_{i=1}^{n} \pi_{1 t} T C R_{t-1}+\sum_{i=1}^{p} \pi_{2 t} F D I_{t-1}+\sum_{i=1}^{m} \pi_{3 t} G E X P_{t-1} \\
+\sum_{i=1}^{j} \pi_{4 t} I N T R_{t-1}+\sum_{i=1}^{k} \pi_{5 t} G F C F_{t-1}+\varepsilon_{5 t}
\end{gathered}
$$

These are the parameters

$$
\begin{gathered}
\left(\alpha_{1 t}, \alpha_{2 t}, \alpha_{3 t}, \alpha_{4 t}, \alpha_{5 t}, \beta_{1 t}, \beta_{2 t}, \beta_{3 t}, \beta_{4 t}, \beta_{5 t}, \delta_{1 t},\right. \\
\left.\delta_{2 t}, \delta_{3 t}, \delta_{4 t}, \delta_{5 t}, \sigma_{1 t}, \sigma_{2 t}, \sigma_{3 t}, \sigma_{4 t}, \sigma_{5 t}, \pi_{1 t}, \pi_{2 t}, \pi_{3 t}, \pi_{4 t}, \pi_{5 t}\right)
\end{gathered}
$$

These tests enable us to determine the direction of causality existing between the variables under review. It reveals the relationship of no causality, unidirectional causality and bidirectional or feedback causality between the variables under consideration. If the parameters of the lagged variables in equations $9,10, \ldots 13$; is statistically significant, it implies that there is a causality relationship between the variables under study. But if the parameters of the lagged variables in equations $9,10, \ldots 13$; is not statistically significant, it means that there is no causal relationship between the variables under study.

\section{Data Analysis}

In this section, the data that were generated for this study was analyzed. The analysis started with a unit root test to determine the stationarity of the variables employed in the variable. The result of the unit root text is presented here under:

Table 4.1. Result of Unit Root Test at Level.

\begin{tabular}{cccc}
\hline Variables & $\begin{array}{c}\text { ADF test- } \\
\text { stat }\end{array}$ & $\begin{array}{c}\text { Critical } \\
\text { Value 5\% }\end{array}$ & $\begin{array}{c}\text { Order of } \\
\text { Integration }\end{array}$ \\
\hline FDI & 1.644633 & -2.9850 & Unit root \\
GFCF & -0.709474 & -2.9850 & Unit root \\
GEXP & -0.341633 & -2.9850 & Unit root \\
Log(TCR) & 0.061253 & -2.9850 & Unit root \\
INTR & -2.564352 & -2.9969 & Unit root \\
\hline
\end{tabular}

Source: Researchers Eview result. 
The above result shows that the entire variable included in the model at level were non-stationary at $5 \%$ critical value. At this point, we difference the variables to see if they will all be stationary at first difference.

Table 4.2. Result of Unit Root at First Difference.

\begin{tabular}{cccc}
\hline Variables & $\begin{array}{c}\text { ADF test- } \\
\text { stat }\end{array}$ & $\begin{array}{c}\text { Critical } \\
\text { Value 5\% }\end{array}$ & $\begin{array}{c}\text { Order of } \\
\text { Integration }\end{array}$ \\
\hline FDI & -3.437184 & -2.9907 & I(1) \\
GFCF & -3.652992 & -2.9907 & I(1) \\
GEXP & -3.260832 & -2.9907 & I(1) \\
Log(TCR) & -4.003735 & -2.9907 & I(1) \\
INTR & -3.061478 & -3.0038 & I(1) \\
\hline
\end{tabular}

Source: Researchers Eview result.

The result of unit root test at first difference shows that the entire variables included in the model were all stationary at first difference. It was also seen from the result that all the variables are stationary at 5\% critical value. Meanwhile having established stationarity, we moved on to conduct co-integration analysis in other to determine if there is a long run relationship between the variables under consideration.

Table 4.3. Result of Johanson Co-integration Test.

\begin{tabular}{ccccc}
\hline $\begin{array}{c}\text { Hypothesized } \\
\text { No. of CE(s) }\end{array}$ & $\begin{array}{c}\text { Likelihood } \\
\text { ratio }\end{array}$ & $\begin{array}{c}\mathbf{5 \%} \text { critical } \\
\text { value }\end{array}$ & $\begin{array}{c}\text { 1\% critical } \\
\text { value }\end{array}$ & Eigenvalue \\
\hline None $* *$ & 190.7669 & 68.52 & 76.07 & 0.981488 \\
At most 1 ** & 91.03395 & 47.21 & 54.46 & 0.946594 \\
At most 2 & 17.78824 & 29.68 & 35.65 & 0.409396 \\
At most 3 & 4.623005 & 15.41 & 20.04 & 0.166390 \\
At most 4 & 0.073251 & 3.76 & 6.65 & 0.002926 \\
\hline
\end{tabular}

Source: Researchers Eviwe result.

The result of the co-integration test shows the existence of at most 2 co-integrating equation in the model. The existences of co-integration suggest that there is a long run relationship between the variables under consideration. Having established con-integration among the variables, we moved on to the ECM which will help us to see the short run dynamics of the model. ECM will enable us determine the speed of adjustment from short-run to long-run equilibrium.

Dependent Variable: D(LOG(GFCF)

Table 4.4. The result of Error Correction Model.

\begin{tabular}{lcccc}
\hline Variable & Coefficient & Std. Error & t-Statistic & Prob. \\
\hline D(LOG(FDI)) & 0.087087 & 0.065246 & 1.334739 & 0.1970 \\
D(LOG(GEXP)) & -0.035851 & 0.113317 & -0.316378 & 0.7550 \\
D(LOG(TCR)) & 0.292687 & 0.252565 & 1.158857 & 0.2602 \\
D(LOG(INTR)) & 0.029781 & 0.181343 & 0.164224 & 0.8712 \\
ECM(-1) & -0.732440 & 0.233536 & -3.136298 & 0.0052 \\
\hline
\end{tabular}

Source: Researchers Eview result
The result of ECM as shown in the table above reviles that the coefficient of $\operatorname{ECM}(-1)$ is negative $(-0.732440)$ as expected, and as well statistically significant at $5 \%$ level of significant. This however implies that $73.24 \%$ of the disequilibrium in the short-run will be corrected in the long-run. This also means that for every disequilibrium in the model, $73.24 \%$ of it will be adjusted on yearly bases. The result also reviles that in the short-run every other variable included in the model positively but insignificantly impact on capital formation in Nigeria with the exception of GEXP which has a negative but insignificant impact on capital formation in Nigeria at the short-run.

Dependent Variable: LOG(GFCF)

Table 4.5. The Result of Log Form of OLS Regression.

\begin{tabular}{|c|c|c|c|c|}
\hline Variable & Coefficient & Std. Error & t-Statistic & Prob. \\
\hline $\mathrm{C}$ & 1.440057 & 0.798600 & 1.803227 & 0.0851 \\
\hline LOG(FDI) & 0.196431 & 0.094434 & 2.080082 & 0.0494 \\
\hline LOG(GEXP) & 0.040753 & 0.095231 & 0.427940 & 0.6729 \\
\hline LOG(TCR) & 0.615184 & 0.076593 & 8.031841 & 0.0000 \\
\hline LOG(INTR) & 0.121271 & 0.204305 & 0.593579 & 0.5588 \\
\hline R-squared & 0.989308 & $\begin{array}{c}\text { Durbin- } \\
\text { Watson stat }\end{array}$ & 1.906871 & \\
\hline F-statistic & 508.9022 & $\begin{array}{l}\operatorname{Prob}(\mathrm{F}- \\
\text { statistic })\end{array}$ & 0.000000 & \\
\hline
\end{tabular}

Source: Researchers Eview result.

The result of the log form of OLS regression as shown in table 4.5 is a long-run model results which indicates that FDI positively and significantly impact on GFCF in Nigeria. The coefficient of FDI is 0.196431 , meaning that $1 \%$ increase in FDI inflow into Nigeria will result to about $19.64 \%$ increase in GFCF in Nigeria. The result also shows that GEXP positively but insignificantly impact on GFCF in Nigeria. The coefficient of GEXP is 0.040753 , implying that $1 \%$ increase in GEXP will result to $4.07 \%$ increase in GFCF in Nigeria. It can also be seen from the result that TCR has a positive and highly significant impact on GFCF in Nigeria. The coefficient of TCR is 0.615184 , which also indicates that $1 \%$ increase in TCR will result to about $61.51 \%$ increase in GFCF in Nigeria. On the same vain INTR has a positive but insignificant impact on the growth of capital formation in Nigeria.

The result of $\mathrm{R}^{2}$ is 0.989308 , which implies that the line of best fit is highly fitted. This means that $98.93 \%$ of the variation in GFCF is explained by the variation in all the independent variables included in the model. The DurbinWatson statistics value of 1.906871 which is approximately 2 shows the absence of serial autocorrelation in the model. However, the result of F-stat is 508.9022 and that of the prob(F-stat) is 0.0000 which is less than 0.05 indicating that the overall regression is statistically significant at $5 \%$ level of significant. 


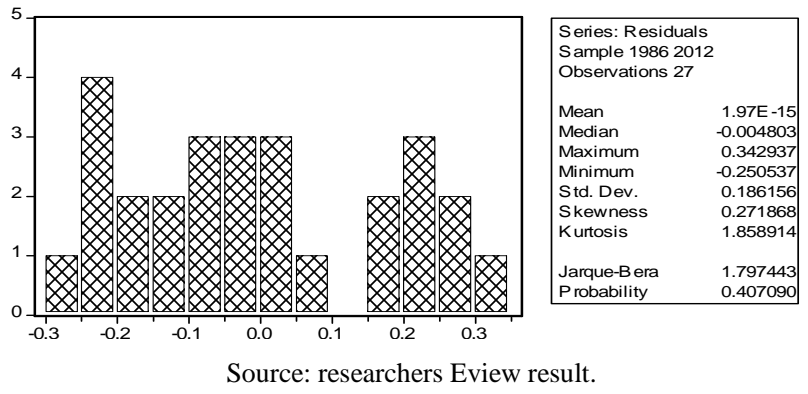

Figure 4.1. Result of the Test of Normality.

The result of the Normality test shows that Jarque-Bera value is 1.797443 with a probability of 0.407090 , this probability value, however is more than 0.05 meaning that we cannot reject the null hypothesis, instead we reject the alternative hypothesis and accept the null hypothesis which states that the residual is normally distribute. Based on this however we conclude that the residual is normally distributed. This result is in line with what was desired.

Table 4.6. The Result of the Test for Serial Autocorrelation. BreuschGodfrey Serial Correlation LM Test:

\begin{tabular}{cccc}
\hline F-statistic & $\mathbf{1 . 1 0 2 4 8 9}$ & Probability & $\mathbf{0 . 3 5 1 3 9 6}$ \\
\hline Obs*R-squared & 2.681128 & Probability & 0.261698 \\
\hline
\end{tabular}

Source: researchers Eview result.

The result of the Breusch-Godfrey test for serial autocorrelation shows that Pro(F-stat) is 0.351396 while $\operatorname{Pro}\left(\mathrm{Obs} * \mathrm{R}^{2}\right)$ is 0.261698 . All these probabilities are greater than 0.05 implying that we cannot reject the null hypothesis instead we reject the alternative hypothesis, and then accept the null hypothesis which states that there is no serial autocorrelation in the model. Based on this, we conclude that there is no autocorrelation in the model. This result is also in line with the Durbin-Watson test of statistics earlier shown in the analysis.

White Heteroskedasticity Test

Table 4.7. The result of the test for Heteroskedasticity.

\begin{tabular}{cccc}
\hline F-statistic & $\mathbf{0 . 3 7 4 2 3 3}$ & Probability & $\mathbf{0 . 9 2 0 7 2 6}$ \\
\hline Obs*R-squared & 3.850379 & Probability & 0.870364 \\
\hline
\end{tabular}

Source: researchers Eview result.

The result of the white heteroskedasticity test shows that the prob(F-stat) is 0.920726 while the $\operatorname{Prob}\left(\mathrm{Obs}_{*} \mathrm{R}^{2}\right)$ is 0.870364 , these are greater than 0.05 implying that we cannot reject the null hypothesis instead we reject the alternative hypothesis and accept the null hypothesis which states that there is no Heteroskedasticity or there is a homoskedasticity in the model. Based on this, we conclude that the model is homoskedastic which is very much desirable. This however can be said to have improved as a result of the introduction of $\log$ in the model.

From the results above it can be seen that the regression is a Best regression model. This is because it met the four conditions required in determining the best regression: the result of $\mathrm{R}^{2}$ is very high $(98.87 \%)$, the model is normally distributed, there is no serial autocorrelation in the model, and there is Homoskedasticity in the model. Based on this, we rely on this model as the best regression model to explain the relationship between the dependent and independent variables.

The result of the granger causality test as shown in table 4.8 reviles that FDI granger causes GFCF, and at the same time GFCF granger causes FDI, indicating that there is a bidirectional causality or feedback effect between FDI and GFCF for the period under study. On the same note, the result reviles that GEXP granger causes GFCF but GFCF does not granger cause GEXP, which indicates a case of unidirectional causality between the variables for the period under study.

From table 4.8 also, it can be seen that TCR granger causes GFCF while GFCF also Granger causes TCR, resulting also to bidirectional causality among the variables for the period under review. Meanwhile it can be seen from the table 4.8 above that INTR and GFCF does not granger cause each other, indicating no causality between the variables. Also FDI and GEXP does not granger cause each other, a case of no causation between the variables also.

Table 4.8. The result of the Granger Causality Test.

\begin{tabular}{|c|c|c|c|}
\hline Null Hypothesis: & Obs & F-Statistic & Probability \\
\hline $\begin{array}{l}\text { FDI does not Granger Cause } \\
\text { GFCF }\end{array}$ & 25 & 40.5856 & $9.1 \mathrm{E}-08$ \\
\hline $\begin{array}{l}\text { GFCF does not Granger Cause } \\
\text { FDI }\end{array}$ & & 10.7487 & 0.00068 \\
\hline $\begin{array}{l}\text { GEXP does not Granger Cause } \\
\text { GFCF }\end{array}$ & 25 & 11.5767 & 0.00046 \\
\hline $\begin{array}{l}\text { GFCF does not Granger Cause } \\
\text { GEXP }\end{array}$ & & 0.04848 & 0.95279 \\
\hline $\begin{array}{l}\text { TCR does not Granger Cause } \\
\text { GFCF }\end{array}$ & 25 & 19.5175 & $2.0 \mathrm{E}-05$ \\
\hline $\begin{array}{l}\text { GFCF does not Granger Cause } \\
\text { TCR }\end{array}$ & & 17.2484 & 4.4E-05 \\
\hline $\begin{array}{l}\text { INTR does not Granger Cause } \\
\text { GFCF }\end{array}$ & 25 & 0.81674 & 0.45607 \\
\hline $\begin{array}{l}\text { GFCF does not Granger Cause } \\
\text { INTR }\end{array}$ & & 0.28689 & 0.75363 \\
\hline $\begin{array}{l}\text { GEXP does not Granger Cause } \\
\text { FDI }\end{array}$ & 25 & 0.78566 & 0.46939 \\
\hline $\begin{array}{l}\text { FDI does not Granger Cause } \\
\text { GEXP }\end{array}$ & & 0.50388 & 0.61165 \\
\hline $\begin{array}{l}\text { TCR does not Granger Cause } \\
\text { FDI }\end{array}$ & 25 & 2.59921 & 0.09921 \\
\hline $\begin{array}{l}\text { FDI does not Granger Cause } \\
\text { TCR }\end{array}$ & & 5.24062 & 0.01479 \\
\hline $\begin{array}{l}\text { INTR does not Granger Cause } \\
\text { FDI }\end{array}$ & 25 & 0.80717 & 0.46013 \\
\hline $\begin{array}{l}\text { FDI does not Granger Cause } \\
\text { INTR }\end{array}$ & & 0.26066 & 0.77312 \\
\hline $\begin{array}{l}\text { TCR does not Granger Cause } \\
\text { GEXP }\end{array}$ & 25 & 1.84077 & 0.18459 \\
\hline $\begin{array}{l}\text { GEXP does not Granger Cause } \\
\text { TCR }\end{array}$ & & 1.59904 & 0.22687 \\
\hline $\begin{array}{l}\text { INTR does not Granger Cause } \\
\text { GEXP }\end{array}$ & 25 & 3.22650 & 0.06103 \\
\hline
\end{tabular}




\begin{tabular}{lccc}
\hline Null Hypothesis: & Obs & F-Statistic & Probability \\
\hline GEXP does not Granger Cause & & 0.22351 & 0.80168 \\
$\begin{array}{l}\text { INTR } \\
\text { INTR does not Granger Cause }\end{array}$ & 25 & 0.36126 & 0.70125 \\
$\begin{array}{l}\text { TCR } \\
\text { TCR does not Granger Cause }\end{array}$ & & 0.10033 & 0.90499 \\
INTR & & & \\
\hline
\end{tabular}

Source: Researchers Eview result

The table also reviles that TCR does not grange cause FDI but FDI granger causes TCR resulting to unidirectional causality between the variables. INTR and FDI does not granger cause each other indicating a case of no causation between the variables. TCR and GEXP does not granger cause each other a case of no causation also. INTR and GEXP also show a case of no causation between the variables and INTR and TCR indicate no causation also.

\section{Conclusions and Recommendations}

This study examined the impact of FDI on GFCF in Nigeria for the period of 1986-2012. The estimation which started with ADF test reviles that all the variables were stationary at first difference, and this led us to conducting a co-integration test which indicated the existence of at most two co-integrating equation in the model. This however implies that there is a long run-run relationship between the variables in the model. At this point we examined the shortrun dynamics of the model by employing the ECM to determine the speed of adjustment from the short-run disequilibrium to long-run equilibrium. The result of the ECM shows that about $73.24 \%$ of the disequilibrium in the model will be corrected in one year. On the same note, the result of the log form of OLS regression indicates that in the long-run, FDI and TCR positively and significantly impact on GFCF in Nigeria. It was also reviled that GEXP and INTR positively but insignificantly impact on GFCF in Nigeria for the period under review. The test of statistics shows that the overall regression statistically significant and the $\mathrm{R}^{2}$ is very high implying that the line of best fit were highly fitted in the model. With the $\mathrm{R}^{2}$ value of about 98\% which is very high, no serial correlation in the model, normal distribution of the residual and no heteroskedasticity, the test of best regression shows that this model is the best regression model. The result of the granger causality test reviles that FDI and GFCF has bidirectional causality, TCR and GFCF also has bidirectional causality, GEXP and GFCF has a unidirectional causality with causation running from GEXP to GFCF. Apart from TCR and FDI that also has a unidirectional causality with causation running from FDI to TCR, the remaining variables in the model show evidence of no causation. Based on these findings, we recommend that efforts should be made to attract more FDI into the country as it has the potential to improve the capital formation in the economy which in the other hand leads to growth in the economy at large. It is also important that government should improve the infrastructural facility in the country as this has a great potential for attracting more FDI into the country.

\section{References}

[1] Adelegan, J.O. (2000), "Foreign Direct Investment and Economic Growth in Nigeria: A seemingly unrelated model", African Review of Money, Finance and Banking, Supplementary Issue of "Savings and Development", 2000, 5-25. Milan, Italy.

[2] Akinlo, A.E. (2004), "Foreign Direct Investment And Growth in Nigeria: An empirical investigation", Journal of Policy Modelling, 26, No. 2: 627-39.

[3] Aremu, J.A. (1997), "Foreign Private Investment: Issues, Determinants and Performance", Paper presented at a workshop on foreign investment policy and practice, organized by the Nigeria Institute of Advance Legal Studies, Lagos, March.

[4] Bakare A.S (2011) "A Theoretical Analysis of Capital Formation and Growth in Nigeria" Far East Journal of Psychology and Business, Vol 3 No 1 April

[5] Beddies, C. (1999), - Investment, Capital Accumulation and Growth: Some Evidence from Gambia: 1964-1998. \| IMF Working Paper 99/117, August.

[6] Bende-Nabende, A. and J.L Ford (1998), "Foreign Direct Investment, Policy Adjustment and Endogenous Growth: Multiplier effect from dynamic for Taiwan 1959-1995", World Development 26(7): 1315-30.

[7] Buckley, P., J. Clegg, and C. Wang (2002), "The Impact of Inward FDI on the Performance of Chinese Manufacturing Firms", Journal of International Business Studies, 33(4): 637-655.

[8] Central Bank of Nigeria (2004), Annual Report and Statement of Accounts, Abuja Nigeria. www.cenbank. org. $12 / 06 / 2010$.

[9] CBN (2006): Central Bank of Nigeria Statistical Bulletin ,December

[10] Chenery, H. B. and A. Stout (1966), "Foreign Assistance and Economic Development", American Economic Review, Vol. 55 pp.679-733.

[11] De Gregorio, J. (2003), "The Role of Foreign Direct Investment and Natural Resources in Economic Development", Working Paper No 196. Central Bank of Chile, Santiago.

[12] Durham, J.B. (2004), "Absorptive Capacity and the Effects of Foreign Direct Investment and Equity Foreign Portfolio Investment on Economic Growth", European Economic Review, 48(2): 285-306.

[13] Gilpin, A. (1987), "Foreign Direct Investments Local Content Requirement and Profit Taxation", The Economic Journal, Vol.108, pp.444-457.

[14] Ghirmay S.G and M.Cadet (1998) "Direct Foreign Investment's Impact on Private Capital Formation in SubSaharan Africa", African Economic and Business Review, Vol. 1, Num 2, 
[15] Ghura, D. and T. Hadji Michael (1996), -Growth in SubSaharan Africa II, Staff Papers, International Monetary Fund, 43, September.

[16] Ghura, D. (1997), -Private Investment and Endogenous Growth: Evidence from Cameroon II , IMF Working Paper 97/165, December.

[17] Johansen, S (1988). Statistical Analysis of Cointegrating Vectors. Journal of Economic Dynamics and Control, 12, 231-54.

[18] Johansen, S. and Juselius, K. (1990). Maximum Likelihood Estimation and Inferences on Cointegration - with applications to the demand for money. Oxford Bulletin of Economics and Statistics, 52, $169-210$

[19] Khan, A. (2007), "Foreign Direct Investment and Economic Growth: The role of Domestic Financial sector", PIDE Working Paper.

[20] Orji, A and P.N. Mba (2011), "Foreign Private Investment, Capital Formation and Economic Growth in Nigeria: a two stage least square approach" Journal of Economics and Sustainable Development, ISSN 2222-1700 (Paper) ISSN 2222-2855 (Online)

[21] Otepola, A. (2002), "Foreign Direct Investment as a factor of Economic Growth in Nigeria." Africa Institute for Economic Development and Planning (JDEP), Dakar, Seregal.

[22] Shiro, A.A (2009), "the Impact of Foreign Direct Investment on the Nigerian Economy", Department of Finance, University of Lagos, Nigeria.

[23] Umah, K.E (2007), "The Impact Of Foreign Private Investment On Economic Development Of Nigeria", Nigeria Journal of Economics and financial research. Vol.1, No.3: 63-72

[24] UNCTAD. (2001, 2004), "World Investment Report", Geneva: United Nations Conference on Trade and Development.

[25] World Bank (1996) "World Debt Tables: External Finance for Developing Countries", Vol. 1 (Analysis and Summary Tables), Washington, D.C. The World Bank.

[26] Xu, B. (2000), "Multinational Enterprises, Technology Diffusion, and Host Country Productivity Growth", Journal ofEconomics, vol. 62, pp 477-493.

[27] Yotopoulos, P. and J. Nugent. (1976), -Economics of Development: Empirical Investigations, New York: Harper and Row. II 